\title{
Hollandaise sauce and the chemistry behind old and new preparation techniques
}

\author{
Anu Hopia \\ Functional Foods Forum, University of Turku, Finland • anu.hopia@gmail.com \\ Merja Sillanpää \\ University of Jyväskylä, Finland • merja.sillanpaa@jyu.fi \\ Maiju Tuomisto \\ Unit of Chemistry Teacher Education, Department of Chemistry, University of Helsinki, Finland • \\ maiju.tuomisto@helsinki.fi
}

\begin{abstract}
Hollandaise sauce has been part of western gastronomy since 1593. Being both an emulsion and a foam, it is a good educational platform for heterophasic systems. Preparing Hollandaise sauce generally includes two phases: forming the foam and forming the emulsion. The sauce is a challenging product and fails easily. Improved preparation techniques have been introduced throughout history. This work combines food historical, scientific and educational perspectives to Hollandaise sauce and introduces an experimental setup to compare the quality of sauces prepared with different techniques.
\end{abstract}

\section{History and characteristics}

Hollandaise sauce is one of the classic sauces in the western gastronomy. As a hot eggemulsified butter sauce its appearance at its best is glossy and smooth. The classical ingredients of hollandaise sauce are egg yolks, melted (often clarified) butter, mixture of water and wine vinegar and occasionally a drop of lemon juice. Structurally it is both an emulsion and a foam.

As with all great gastronomic inventions, the history and the inventor of hollandaise sauce is unknown. Some sources claim that the sauce was developed in the Netherlands, from where it was taken to France by the Huguenots. The sauce is mentioned as early as in 1593 in a Dutch cookbook. French Pierre La Varenne describes a recipe resembling hollandaise sauce in his book La cuisinier Francoise from 1651. La Varenne's sauce had fresh butter, vinegar, egg yolk and nutmeg. Thereafter, egg disappeared from the sauce recipes for a time: emulsion could be established with just butter! In later recipes egg was again included as an integral ingredient.

\section{Microscopic structure of sauce hollandaise}

Preparing hollandaise sauce requires two steps: 1 . Preparing foam by cooking egg yolk into desired consistency, and 2. Forming the emulsion by mixing the molten butter into the sauce base. Large air bubbles and smaller emulsion droplets are easily identified in a light microscope (Figure 1). 


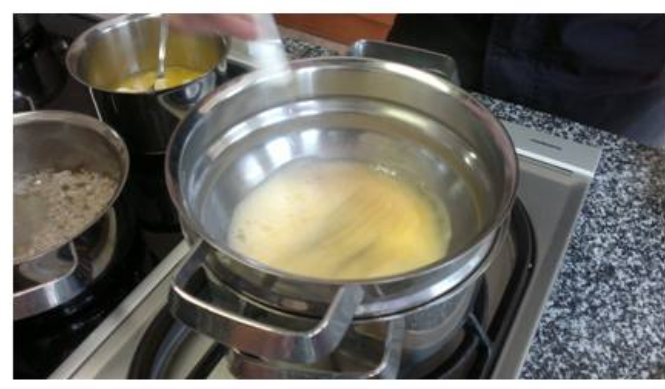

1. Building the foam by cooking egg yolk in bain marie

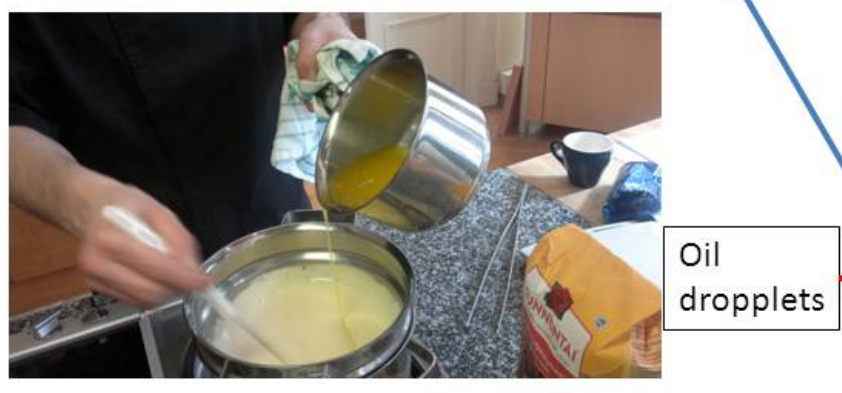

2. Emulsifying molten butter into the sauce base

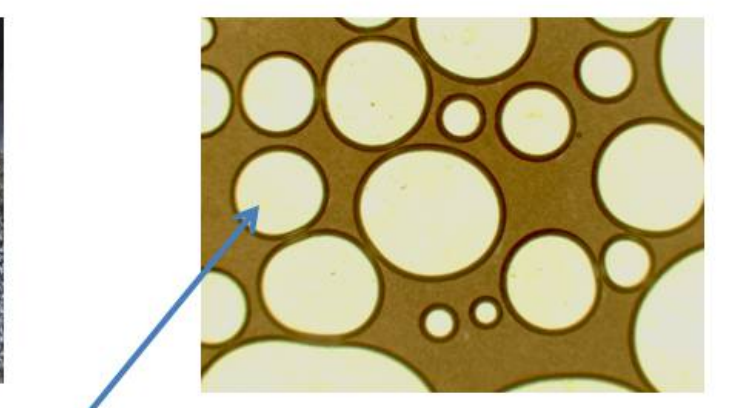

Air bubbles

Light microscope picture (40x) of the foam

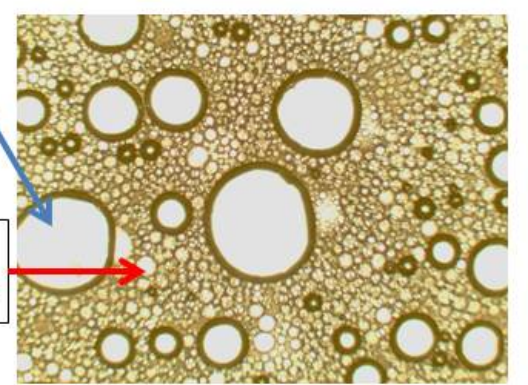

Light microscope picture (40x) of the sauce hollandaise

Figure 1. The two steps to making hollandaise sauce: forming the foam and forming the emulsion.

Egg yolk proteins cooked and coagulated into desired consistency form a gel that retains air bubbles in the foam. The denaturation level of egg yolk proteins is a critical parameter when preparing the foam: if the yolk proteins do not denature sufficiently, the sauce remains runny and air bubbles leak out from the structure. However, if cooking temperature rises too high, egg proteins denature extensively and form lumps of overcooked egg. Egg yolk curdles.

In the formation of emulsion, surface active ingredients, especially egg yolk phospholipids, act as emulsifying agents that keep oil and water phases separated in the mixture. As egg yolks are rich in phospholipids, there is usually a sufficient amount of emulsifying agents available in the process. However, a few other phenomena may cause failure in forming emulsion in Hollandaise sauce. Firstly, oil droplet size needs to be sufficiently small to have smooth and silky texture, which is required to keep oil and water phases separated and prevents oil from leaking out of the structure. Traditional recipes suggest adding small amounts of oil into the sauce base, preferably as a thin string, to ascertain the small droplet size of the emulsified oil. Modern recipes use efficient technologies, such as pressure (siphon), for emulsifying and foaming. Secondly, emulsion of hollandaise sauce may fail if the fat crystallizes due to butterfat's low crystallization 
temperature (app. $38^{\circ} \mathrm{C}$ ). To avoid this, temperature of hollandaise sauce needs to be kept above the crystallization temperature of butterfat.

The structure of emulsion requires three elements: oil (for oil droplets), emulsifying agent (for surface active ingredient) and water (an extremely thin water layer is required for the surface of each oil droplet). If the system runs out of any of these ingredients the emulsion fails, which is usually seen as oil leaking out of the system. The third possible reason for emulsion failing to form is running out of any of the three critical ingredients of the emulsion. Usually there is a sufficient amount of molten butter available. Furthermore, the egg yolks provide a sufficient source of emulsifying agents into the system. However, sometimes the system runs out of the third critical ingredient - water. Adding a small amount of lemon juice or any other source of free water introduces this third element into the system.

\section{Different techniques for preparing hollandaise sauce}

As hollandaise sauce is easily ruined, several techniques for its preparation have been suggested. Hollandaise sauce was first introduced by famous French chef Marie Antoine Carême (1784-1833). His technique of whisking the air into egg yolk and water-based ingredients in a bain-marie (= making the foam first) and emulsifying molten butter into the foam is still the most often used technique in cookbooks. Careme, the first celebrity chef in the world, dealt with the sauce in his work L'art de la cuisine française au XIXe siècle. A major theme of the book was sauces that he wanted to rebuild. Careme introduced new silk smooth sauces he had developed; these became an important part of Frech gastronomy later on.

Approximately hundred years later another French chef Georges Auguste Escoffier (1847-1935) introduced a technique of reversed order; that is whisking the butter into warm yolk-water mixture (= making the emulsion first) and cooking and whisking the mixture into desired consistency. By diluting egg yolk before cooking, the risk of overcooking and egg yolk curdling was minimized.

Modern cookbooks have also introduced a fast technique where emulsion and foam are formed simultaneously. These recipes suggest adding all the ingredients while still cold to the sauce pan and then start heating gently while whisking. The butter melts slowly and gets emulsified while air is whisked in and egg yolk protein gets denatured. This technique is quick and simple but does it result in a good structure of foam and emulsion?

Recent innovations in the kitchen provide many new tools for precise temperature control and efficient emulsifying and foaming. Temperature controlled water baths (Figure 2) enable the cooking of egg yolk-water mixture in exact temperature (such as $65^{\circ} \mathrm{C}$, which is tested to provide optimal gel strength in this recipe) and blending in melted butter and building strong and stable foam with a pressurized siphon (Figure 3). 


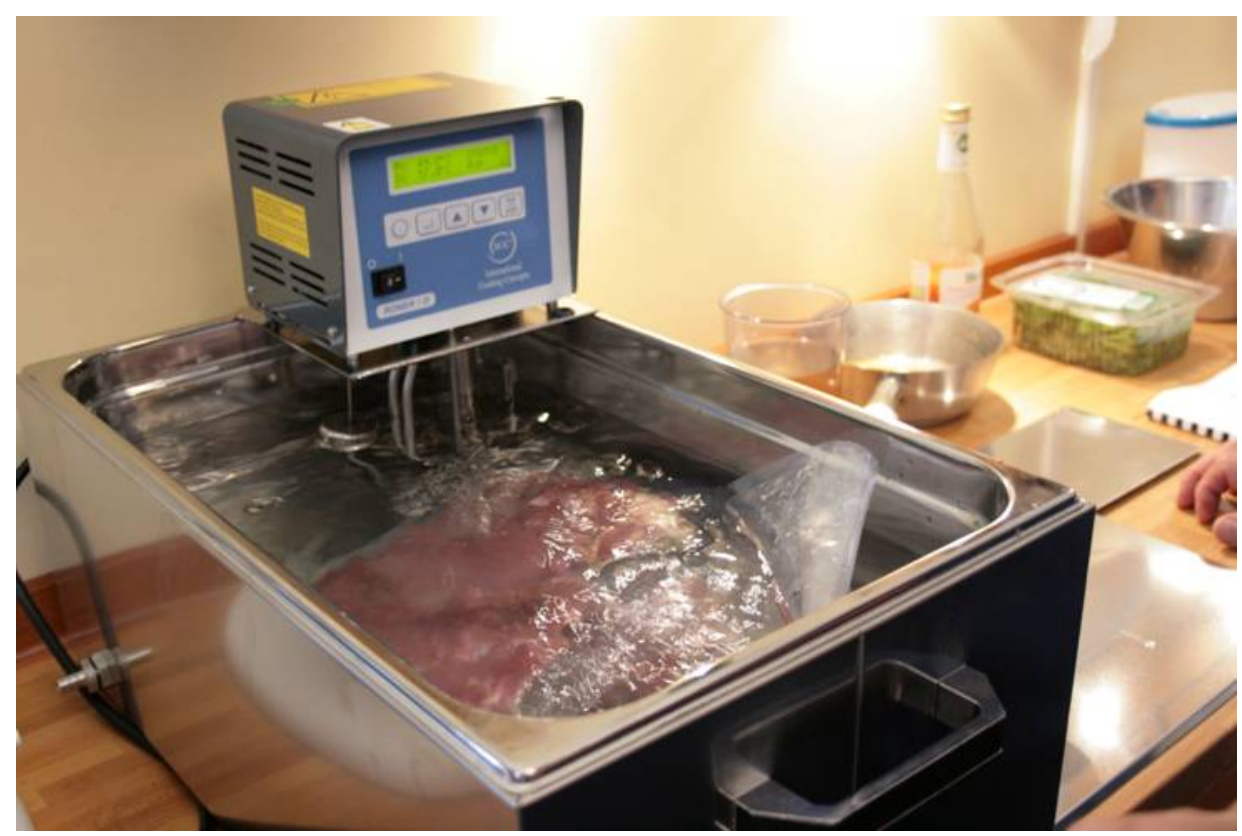

Figure 2. A water bath equipped with thermostat and pump for water circulation is increasingly common equipment in the kitchen. It enables the cooking of food based on precise temperature control.

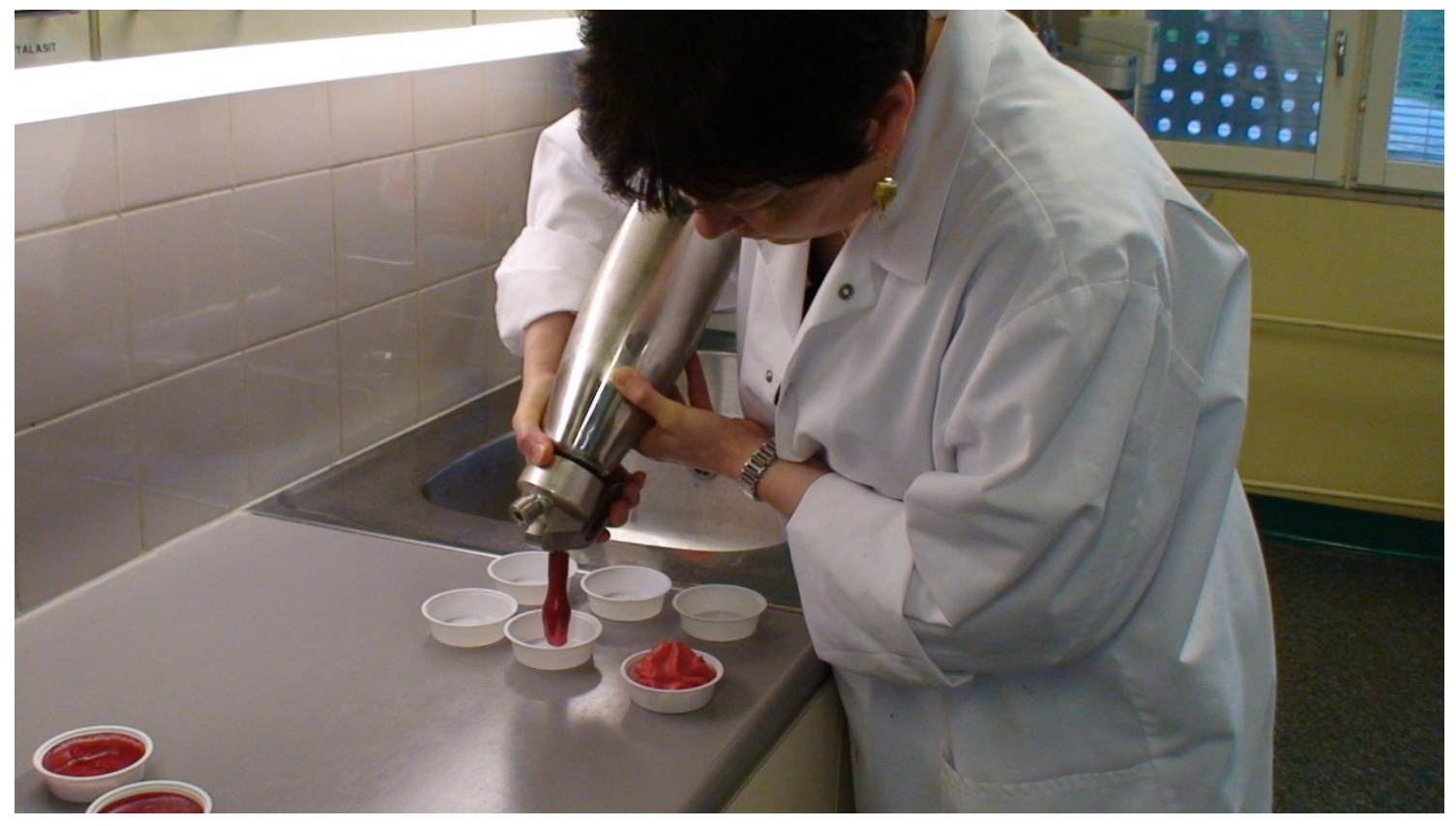

Figure 3. Liquid can be turned into foam and/or emulsion instantly by using a pressure siphon in the kitchen. It works similarly to a soda siphon (used to make carbonated drinks) but its structure, vents and valves are designed to work for viscous liquids. It is basically a steel bottle equipped with a vent and a valve. Once filled with liquid, the bottle can be pressurized by using nitrous oxide cartridges. When the valve is opened the pressure within the bottle drives the liquid out through a tube (nozzle).

All the mentioned techniques have their benefits and limitations. In the original and still most popular technique introduced by Carême, effective foaming and gas retention is achieved due to strong gel formation. However, when egg yolks reduce to small volume, 
there is an increased risk of overcooking and thus curdling yolk proteins. In the revised technique by Escoffier the sauce is already at its final volume when cooked, so the consistency of sauce is easier to control and the risk of overcooking is minimized. However, as the gel is not as strong as in the previous case, it can lead to poor gas retention and thus smaller foam volume. In the fast technique where foam and emulsion are formed simultaneously, the foam formation, gas retention and good emulsion may have to be sacrificed. In the modern version the new technologies offer improved temperature control and structure formation. It is not known, however, how the new techniques compare to the traditional ones.

\section{Experiment}

Aim of this experiment is to study the formation of emulsion and foam by using traditional and new techniques to prepare hollandaise sauce. The experiment can be conducted in collaboration with home economics and chemistry teachers, for example by studying the characteristics of emulsion and foam in the chemistry class and the history and preparation of hollandaise sauce in home economics class. Hollandaise sauce can be served with asparagus or white fish.

\subsection{Conducting the experiment}

Prepare hollandaise sauce by using 4 different techniques and compare the products in the blind test.

Ingredients for each experiment:

- $10 \mathrm{ml}$ of the mixture (see preparation below)

- 2 eggyolks

- $125 \mathrm{~g}$ butter

- $15 \mathrm{ml}$ lemon juice

Preparing the mixture:

Combine the ingredients listed below and cook until the volume has reduced to 1/ 3 :

- $120 \mathrm{ml}$ water

- $30 \mathrm{ml}$ white wine vinegar

- $10 \mathrm{ml}$ white peppers grounded 


\section{Experiment \#1 (“Carême”)}

1. Melt butter.

2. Add eggyolks to mixture.

3. Carefully heat the mixture in a kettle while whisking constantly until it thickens, keep temperature below $65^{\circ} \mathrm{C}$.

4. Remove from heat and establish emulsion by adding molten butter gradually as a thin ribbon.

5. Add lemon juice and maintain $60^{\circ} \mathrm{C}$ temperature until served.

\section{Experiment \#2 ("Escoffier")}

1. Melt butter.

2. Combine and heat the yolks and mixture.

3. Whisk in molten butter.

4. Whisk and heat carefully in a kettle, cook until desired consistency.

5. Add lemon juice and keep temperature $60^{\circ} \mathrm{C}$ until served.

\section{Experiment \#3 (Fast)}

1. Put all the ingredients in a saucepan cold.

2. Turn on the heat and start stirring.

3. Continue cooking until butter has melted and sauce has reached desired consistency.

4. Maintain $60^{\circ} \mathrm{C}$ temperature until served.

\section{Experiment \#4 (Modern)}

Note: This is recommended for advanced level only.

1. Combine mixture and egg yolks in a vacuum pack and seal.

2. Blend thoroughly and cook in $65^{\circ} \mathrm{C}$ water bath for $30 \mathrm{~min}$.

3. Melt butter.

4. Remove cooked eggyolk from bag and blend in butter mixture until fully emulsified.

5. Add lemon juice.

6. Transfer mixture into a siphon, charge with 1-2 cartridges of nitrous oxide and shake vigorously. Keep in $60{ }^{\circ} \mathrm{C}$ water bath.

7. Serve directly from siphon.

Compare the products by microscope and in a blind test using for example the questionnaire in figure 4:

- quality of foam (bubble size by microscope)

- quality of emulsion (droplet size by microscope)

- (quality of emulsion (identification of coagulated protein lumps)) 
- $\quad$ sensory quality

- smoothness/sharpness of taste

Note: Large emulsion droplets usually result in a sharper taste.

- smoothness/graininess of structure

Note: Overcooking proteins usually results in coagulation of egg yolk proteins,

which causes graininess of the structure.

\title{
Evaluation sheet
}

\begin{abstract}
TASTE
Smooth — Sharp
\end{abstract}

\section{STRUCTURE}

Smooth Grainy

Structure analysis by light microscope (compare bubble and droplet size of each sauce

\begin{tabular}{|l|l|l|l|l|}
\hline & A & B & C & D \\
\hline Bubble size & & & & \\
\hline Droplet size & & & & \\
\hline
\end{tabular}

Figure 4. Questionnaire for the blind test of the experiment

\section{Experimental applications in chemistry and home economics teaching}

Preparing hollandaise sauce requires more than the basic cooking skills of 7th grade home economics, even though the key chemical concepts in preparing the sauce are included in 7th grade chemistry education (Finnish National Board of Education, 2004). The key concepts include: compound, foam, gel and emulsion. However, protein structure and chemical processes (denaturation, coagulation) are not introduced until 8th or 9th grade chemistry.

Preparing the sauce in the context of molecular gastronomy is probably most useful in 9th grade optional home economics, a home economics course in upper secondary school, 
as part of an upper secondary school home economics diploma or in an optional inquirybased chemistry course dealing with molecular gastronomy.

The first and second methods (\#1 and \#2) of preparing the sauce can be performed in 9th grade home economics of basic education. It is also possible at the time to go over the key concepts in chemistry and to explain history and study of science in relation to the recipes (Carême vs. Escoffier).

Some upper secondary schools provide the option to study home economics. Home economics in upper secondary school continues from home economics in basic education and aims to improve the students' individual skills in the kitchen. Education generally consists of two basic courses and one upper secondary school diploma course (Kotitalousopettajien liitto, 2013).

Upper secondary school diploma is an applied course (38 h) consisting of a diploma work and an essay. Preparing hollandaise sauce by four methods fulfils many of the diploma's requirements as the student learns to:

- Acknowledge his home economics skills and is inspired to improve them

- Use different ingredients and methods critically

- Appreciate the importance of national and international cuisine

- Use the central vocabulary of home economics

- Use different home economics sources critically and diversely

- Apply theoretical knowledge to practice. (Finnish National Board of Education, 2012)

\section{References}

Kotitalousopettajien liitto. (2013). Kotitalous-oppiaine. Helsinki: Kotitalousopettajien liitto. Retrieved 8.4.2013 from http:// kotitalous.org/ kotitalousopettajuus/ kotitalous-oppiaine

Finnish National Board of Education. (2004). National core curriculum for comprehensive school 2004. Helsinki: Finnish National Board of Education.

Finnish National Board of Education. (2012). Upper secondary school home economics diploma 2012- 2013. Helsinki: Finnish National Board of Education. Retrieved 8.4.2013 from http:// www.edu.fi/download/ 140817_lukiodiplomit_kotitalous_2012_2013.pdf 